\title{
Dynamic plasma biochemical profile changes of weaning piglets fed diets containing different levels of Bacillus spp. as a probiotic product
}

\author{
Idriceanu Lavinia 1, Dumitru Mihaela ${ }^{1}$, Lefter Nicoleta Aurelia ${ }^{1}$, \\ Gheorghe Anca ${ }^{1}$ and Habeanu Mihaela ${ }^{1}$ \\ *Corresponding author: mihaela.dumitru22@yahoo.com
}

${ }^{1}$ Department of Animal Nutrition, National Research-Development Institute for Biology and Animal Nutrition (INCDBNA), Balotesti, 077015, Romania

\section{ABSTRACT}

In this study, an experiment was conducted to investigate the effects of two levels of Bacillus subtilis ATCC 6051a (BS), respectively Bacillus licheniformis ATCC 21424 (BL) administered as direct-fed microbial DFM probiotic bacteria on plasma biochemical profile of weaning piglets fed diets. A total of 100 piglets, $30 \pm 3$ day-old, with initial average body weight (BW) of $8.53 \pm 0.17 \mathrm{~kg}$ were randomly distributed to 5 homogeneous groups (C, E1-BS 1\%, E2-BS 3\%, E3-BL 1\%, E4-BL 3\%,), 2 replicates/group with 10 piglets/pens, for 16 days of biological trial. The doses used were: $1 \%$ low dose in a concentration of $1.6 \times 10^{9} \mathrm{CFU}$ spores $\mathrm{g}^{-1}$ feed, and 3\% high dose in a concentration of $4.8 \times 10^{9} \mathrm{CFU}$ spores $\mathrm{g}^{-1}$ feed. Results showed that BS supplementation affected plasma concentration of GGT $(\mathrm{P}<0.017)$, TG $(\mathrm{P}<0.048)$ and $\mathrm{Mg}(\mathrm{P}<0.0001)$. No effect $(\mathrm{P}>0.05)$ as diet*day interaction on plasma metabolic profile was observed. In conclusion, administration of Bacillus spp. maintains the concentration of blood plasma parameters within the physiological ranges, without affecting the piglet's health status.

Keywords: Weaning, Bacillus spp., Probiotics, Plasma profile

\section{INTRODUCTION}

Nutrition, feeding strategies and weaning stress in piglets are some very important factors that have a major influence for economic loss to pig farmers (Kim et al., 2013; Dowarah et al., 2017). Weaning is one of the most difficult and stressful periods for piglets that can encounter in commercial swine production, and it is characterized through incomplete development of the enzymatic system and by the action of factors generating stress that modifies 
the secretion of the hormones and blood components (Griggs and Jacob, 2005; Whittemore and Green, 2006; Habeanu et. al., 2015).

In the past, to prevent economic loss resulting from diseases caused by weaning stressors factors, pig farmers have been used antibiotics. However, some of the European countries, as affirmed Diamini et al., (2017), have been banned the use of antibiotics as growth promoters in pigs' diet.

One of the most potential alternatives are probiotics (Baker et al., 2013, Zhao and Kim, 2015) known as direct-fed microbial (DFM); probiotics are defined as non-pathogenic live microorganisms, being represented by a single strain or a mixture of different bacteria, which when administered to animals have beneficial effects on health status, equilibrating intestinal flora composition (FAO/WHO, 2002; Dowarah et al., 2017).

Generally, as probiotics-DFM are used Gram-positive bacteria from genus Bacillus (B. subtilis, B. licheniformis, B. megaterium, B. amyloliquefaciens), Lactobacillus spp. (L. acidophilus, L. brevis, L. casei; L. delbrueckii, L. fermentum, L. lactis, L. paracasei, L. plantarum, L. reuteri, L. rhamnosus; L. salivarius), Bifidobacterium, Saccharomyces, Streptococcus, Enterococcus etc. (Lia and Nyachoti, 2017; Dumitru et al., 2020).

According to spore-forming criteria, Bacillus spp. are an excellent group with high probiotics properties due to the presence of spores, a way to protect against different environmental factors, which involve thermostability in feed pelleting processes, for example, with a minimal reduction of their viability.

Some of Bacillus spp. that are used as probiotics can produce toxins (Gaggia et al., 2010); however, in case of Bacillus subtilis and Bacillus licheniformis has been listed as non-toxigenic bacteria without hemolysis pathogenicity (Dumitru et al., 2018; Dumitru et al., 2019), involving that biological supplements to livestock diets (EFSA, 2010). Also, probiotics have been reported to decrease blood cholesterol (Ooi and Liong, 2010), reducing metabolic reactions that produce toxic substances, secret vitamins and antimicrobial compounds such as bacteriocins (Hemaiswarya et al., 2013).

Serum biochemistry is an important indicator of health and disease in animals and has become indispensable in the diagnosis, treatment or prognosis of many diseases. The weaning period is a complex process associated with many challenges in term of health, growth slowdown (Habeanu et al., 2015). Determination of the serum biochemistry reflects the physiological responsiveness of the animals to its internal and external environment (Esonu et al., 2001).

The aim of this paper consists to test the efficacy of two Bacillus strain (B. subtilis ATCC 6051a and B. licheniformis ATCC 21424) as probiotics products in piglets diets on plasma biochemical profile in the weaning period. 


\section{MATERIALS AND METHODS}

Animals were treated following the Romanian Law 305/2006 for handling and protection of animals used for experimental purposes. The feeding trial was conducted on the experimental farm of National Research-Development Institute for Biology and Animal Nutrition, Balotesti according to Law 43/2014/Romania. Experimental procedures were approved by the Ethical Committee of INCDBNA Balotesti, Romania (No. 5183).

\section{Bacterial strain, culture medium and growth conditions}

Bacillus subtilis ATCC 6051a (BS) and Bacillus licheniformis ATCC 21424 (BL) as bacterial strains used as DFM was acquired from the American Tissue Culture Collection (ATCC) in the form of freeze-dried. The probiotic properties of BS and BL strain were analyzed in vitro and presented in previous studies (Dumitru et al., 2018; Dumitru et al., 2019; Dumitru et al., 2020). The cultures growth was done following parameters described by Dumitru et al. (2020).

\section{Animals, experimental design and diets}

The feeding trial was carried out on 100 weaned piglets, $30 \pm 3$ days old, with an average initial body weight of $8.53 \pm 0.17 \mathrm{~kg}$, individually identified by ear-tag. Piglets were randomly assigned into 5 groups and distributed in 10 pens (10 piglets/pen), two replicates for each group. Thedietary treatments shown in Table 1 included: 1 ) a negative control diet (C diet) that contains a basal diet; 2) E1-BL 1\% diet that consists on $C$ diet + a low dose of $B$. licheniformis ATCC 214241 (1.6 x $10^{9} \mathrm{CFU}$ viable spores $\left.\mathrm{g}^{-1} \mathrm{feed}\right) ; 3$ ) E2-BL 3\% diet, that consists on C diet + a high dose of B. licheniformis ATCC 21424 (4.8 x $10^{9} \mathrm{CFU}$ viable spores $\mathrm{g}^{-1}$ feed); 4) E3-BS $1 \%$ diet that consists on $\mathrm{C}$ diet $+\mathrm{a}$ low dose of $B$. subtilis ATCC 6051 a (1.6 x $10^{9}$ CFU viable spores g-1 feed; 5) E5BS $3 \%$ diet that consists on C diet + a high dose of $B$. subtilis ATCC 6051a (4.8 x $10^{9} \mathrm{CFU}$ viable spore $\mathrm{g}^{-1}$ feed).

To determine the viability of spores-forming, the vegetative cell was inactivated by thermal treatment $\left(80^{\circ} \mathrm{C}, 10 \mathrm{~min}\right)$. Serial dilutions in PBS (phosphate buffered saline solution) on nutrient medium agar (g/L: tryptone 10; meat extract 5; sodium chloride 5; bacteriological agar 15; pH medium $7.2 \pm 2$ before autoclaving) were followed by incubation in a shaker-incubator $(200 \mathrm{rpm})$, at $37^{\circ} \mathrm{C}$ in an aerobic atmosphere for $24 \mathrm{~h}$. The biomass surviving spores were collected by centrifugation $(5,000 \mathrm{rpm}, 10 \mathrm{~min}, 4 \mathrm{C})$, washed twice, and then resuspended in PBS solution.

The feed formulation was designed to meet all nutritional requirements specific to TOPIGS hybrid.

Feed was administered ad libitum in the flour form, two meals/day at 08:00 and 14:00 $\mathrm{h}$ with permanent access to water throughout the experimental period. 
Table 1. Compositions of the basal diet of piglets during weaning crisis

\begin{tabular}{llllll}
\hline Items \% & Control & $\begin{array}{l}\text { E1 BS- } \\
\mathbf{1 \%}\end{array}$ & $\begin{array}{l}\text { E2 BS- } \\
\mathbf{3 \%}\end{array}$ & $\begin{array}{l}\text { E3 BL- } \\
\mathbf{1 \%}\end{array}$ & $\begin{array}{l}\text { E4 BL- } \\
\mathbf{3 \%}\end{array}$ \\
\hline Maize & & 33.48 & 33.48 & 33.48 & 33.48 \\
Sorghum & 33.48 & 25 & 25 & 25 & 25 \\
Peas & 25 & 17 & 17 & 17 & 17 \\
Soybean meal & 17 & 13 & 13 & 13 & 13 \\
Maize gluten & 13 & 3 & 3 & 3 & 3 \\
Milk replacer & 3 & 5 & 5 & 5 & 5 \\
DL methionine & 5 & 0.1 & 0.1 & 0.1 & 0.1 \\
L- Lysine & 0.1 & 0.21 & 0.21 & 0.21 & 0.21 \\
Calcium carbonate & 0.21 & 1.6 & 1.6 & 1.6 & 1.6 \\
Phytase & 1.6 & 0.01 & 0.01 & 0.01 & 0.01 \\
Monocalcium phosphate & 0.01 & 0.4 & 0.4 & 0.4 & 0.4 \\
Salt & 0.4 & 0.1 & 0.1 & 0.1 & 0.1 \\
Premix choline & 0.1 & 0.1 & 0.1 & 0.1 & 0.1 \\
Vitamin-mineral premix & 0.1 & 1 & 1 & 1 & 1 \\
\hline DFM** & 1 & 1.0 & 3.0 & 1.0 & 3.0 \\
\hline Chemical composition \% (g- feed) & 0.0 & & & & \\
\hline Metabolizable energy & 3237.31 & 3237.31 & 3237.31 & 3237.31 & 3237.31 \\
(EM, Kcal/ Kg) & 18.23 & 18.23 & 18.23 & 18.23 & 18.23 \\
Crude protein (CP) & 1.2 & 1.2 & 1.2 & 1.2 & 1.2 \\
Lysine & 0.59 & 0.59 & 0.59 & 0.59 & 0.59 \\
Methionine + Cystine & & & & & \\
\hline
\end{tabular}

${ }^{*} \mathrm{ME}$ was calculated based on feed composition and theoretical coefficients. ${ }^{*}$ The vitamin-mineral premix contained (/kg feed): 10000 IU vitamin A; 2000 IU vitamin D3; 30 IU vitamin E; 3 mg vitamin K3; 2 mg vitamin B1; 6 mg vitamin B2; 20 mg vitamin B3; $13.5 \mathrm{mg}$ vitamin B5; 3 mg vitamin B6; 0.06 mg vitamin B7; $0.8 \mathrm{mg}$ vitamin B9; $0.05 \mathrm{mg}$ vitamin B12; $10 \mathrm{mg}$ vitamin C; $30 \mathrm{mg} \mathrm{Mn;} 110 \mathrm{mg}$ Fe; $25 \mathrm{mg} \mathrm{Cu} ; 100 \mathrm{mg} \mathrm{Zn}$; $0.38 \mathrm{mg} \mathrm{I} ; 0.36 \mathrm{mg}$ Se; $0.3 \mathrm{mg}$ Co; $60 \mathrm{mg}$ antioxidant.

${ }^{*}$ DFM: direct feed microbial; C, basal diet; BS, B. subtilis ATCC 6051a; E1-BS 1\%, basal diet + low dose of BS ( $1.6 \times 10^{9} \mathrm{CFU}$ spores g-1 feed); E2-BS $3 \%$, basal diet + high dose of BS ( $4.8 \times 10^{9} \mathrm{CFU}$ spores g- 1 feed); $\mathrm{BL}, \mathrm{B}$. licheniformis ATCC 21424; E1-BL 1\%, basal diet + low dose of BL $\left(1.6 \times 10^{9} \mathrm{CFU}\right.$ spores g- 1 feed); E2BL $3 \%$, basal diet + high dose of BL ( $4.8 \times 10^{9} \mathrm{CFU}$ spores g- 1 feed).

Pens measured $2.40 \mathrm{~m} \times 1.80 \mathrm{~m} \times 0.800 \mathrm{~m}$, each with the slatted plastic floor, in an environmentally controlled isolation. All pens were equipped with one self-feeder and a nipple drinker. Ventilation was delivered by a mechanical system with automatic adjustments. The room temperature was approximately $25^{\circ} \mathrm{C}$.

Chemical analyses and sampling

Blood samples (approximately $6 \mathrm{~mL}$ ) were achieved at the beginning and the end of the experimental period, from the jugular vein, in heparinized tubes. Blood was centrifuged at $3000 \mathrm{rpm}$ for 15 minutes (iFuge D06, Neuation Technologies Pvt. Ltd, India) and plasma obtained was placed in Eppendorf safe-lock tubes, and stored in the freezer at $-20^{\circ} \mathrm{C}$ until analysis.

A semiautomatic Analyzer Spotchem EZ SP-4430 (Arkray Inc., Kyoto, Japan), and commercial reagents (SPOTCHEMTM Reagent Strip) were used to 
measure the following plasma biochemical profiles: proteic (T-Pro, total protein; T-Bil, total bilirubin; Alb, albumin; Cre, creatinine; BUN, blood urea nitrogen; UA, uric acid), energetic (T-Chol, total cholesterol; HDL-C, highdensity lipoprotein cholesterol; TG, triglycerides, Glu, glucose), enzymatic (GGT, gamma-glutamyltransferase; GOT, glutamic-oxaloacetate transaminase; GPT, glutamyl-pyruvate transaminase; CPK, creatine phosphokinase), and mineral (Ca, calcium; Mg, magnesium; $\mathrm{P}$, phosphorus)

\section{Statistical analysis.}

All data recorded were expressed as mean values and standard error of the mean (SEM). For all measurements, the individual pig was considered the experimental unit. The data were submitted to variance analysis using the general linear model (GLM) of the SPSS program (SPSS 2011). The response to the dietary treatment was variable dependent, and the diet was a fixed factor. Differences were considered significant at $\mathrm{P}<0.05$.

\section{RESULTS AND DISCUSSION}

\section{Plasma protein profile}

Nutrition plays an important role in health and blood parameters are important markers for these. Thus, the plasma biochemical parameters reflect the animal health and give us a better picture on the physiological effects of nutrients, respectively their use by the body (Washington and Hoosier, 2012; Dong et al., 2013).

In our study, the results of plasma protein parameters are summarized in Table 2.

Regarding T-Pro, they recorded lower values than normal (Merck, 2014). According to Kabalin et al., (2017), in the piglet's due to complete underdevelopment of the liver, protein synthesis is limited, causing low concentrations of total serum protein. In our study the lowest values $(\mathrm{P}<0.001)$ were noticed in $\mathrm{d} 7$ compared to $\mathrm{d} 14$ and $\mathrm{d} 17$. Contrary to our results Dong et al., (2013) and Dowarah et al., (2018) observed that dietary supplementation of L. plantarum and B. subtilis in weaned piglets, increased serum concentrations of T-Pro and Alb compared to control animals in 14 days of feeding.

The final metabolite of protein and amino acid catabolism in animals is plasma urea nitrogen (Chen et al., 2016). Plasma urea nitrogen it is been used as an indicator of amino acid utilization efficiency and relates the status of protein metabolism (Jin et al., 2010).

The values of PUN obtained by us are within the range $(8.2-25 \mathrm{mg} / \mathrm{dL}$, Merk, 2014), what implies that direct-microbial feed has no negative effect on piglets health. Our results including BUN at addition of Bacillus strains as source of DFM in piglets feed is consistent with Hu et al. (2020) who reported 
that complex probiotic based on $B$. subtilis, $(1.0 \times 109 \mathrm{CFU} / \mathrm{g})$ and $B$. licheniformis $(1.0 \times 109 \mathrm{CFU} / \mathrm{g})$ had no significant effect on BUN concentration.

Table 2. Plasma protein profile at $7 \mathrm{~d}, 14 \mathrm{~d}$ and $17 \mathrm{~d}$ after weaning of piglets

\begin{tabular}{|c|c|c|c|c|c|c|c|c|c|c|}
\hline \multirow[b]{2}{*}{ Items } & \multirow[b]{2}{*}{ Day } & \multicolumn{5}{|c|}{ Diet } & \multirow[b]{2}{*}{ SEM } & \multicolumn{3}{|c|}{ P-value } \\
\hline & & $\mathrm{C}$ & $\begin{array}{l}\text { E1- } \\
\text { BS } \\
1 \%\end{array}$ & $\begin{array}{c}\text { E2- } \\
\text { BS } \\
3 \%\end{array}$ & $\begin{array}{l}\text { E3- } \\
\text { BL } \\
1 \% \\
\end{array}$ & $\begin{array}{l}\text { E4- } \\
\text { BL } \\
3 \%\end{array}$ & & Diet & Day & $\begin{array}{c}\text { Diet* } \\
\text { day }\end{array}$ \\
\hline \multirow{4}{*}{$\begin{array}{l}\text { T-Pro } \\
\text { g/dL }\end{array}$} & d7 & 4.38 & 4.63 & 4.60 & 5.25 & 5.10 & \multirow{4}{*}{0.08} & \multirow{4}{*}{0.117} & \multirow{4}{*}{0.0001} & \multirow{4}{*}{0.307} \\
\hline & d14 & 5.53 & 5.40 & 5.20 & 5.45 & 5.08 & & & & \\
\hline & $\mathrm{d} 17$ & 5.55 & 5.30 & 5.60 & 5.90 & 6.05 & & & & \\
\hline & Total & 5.15 & 5.11 & 5.13 & 5.53 & 5.41 & & & & \\
\hline \multirow{4}{*}{$\begin{array}{c}\text { Alb } \\
\text { g/dL }\end{array}$} & $\mathrm{d} 7$ & 2.68 & 2.68 & 2.63 & 2.98 & 2.85 & \multirow{4}{*}{0.39} & \multirow{4}{*}{0.543} & \multirow{4}{*}{0.305} & \multirow{4}{*}{0.424} \\
\hline & $\mathrm{d} 14$ & 2.78 & 2.80 & 3.55 & 3.15 & 2.90 & & & & \\
\hline & $\mathrm{d} 17$ & 2.75 & 2.85 & 3.03 & 3.23 & 3.23 & & & & \\
\hline & Total & 2.73 & 2.78 & 3.07 & 3.12 & 2.99 & & & & \\
\hline \multirow{4}{*}{$\begin{array}{c}\text { PUN } \\
\mathrm{mg} / \mathrm{dL}\end{array}$} & $\mathrm{d} 7$ & 14.75 & 17.50 & 16.50 & 15.50 & 15.00 & \multirow{4}{*}{0.61} & \multirow{4}{*}{0.842} & \multirow{4}{*}{0.0001} & \multirow{4}{*}{0.883} \\
\hline & d14 & 19.00 & 20.00 & 16.75 & 16.75 & 17.50 & & & & \\
\hline & $\mathrm{d} 17$ & 20.75 & 23.00 & 22.50 & 24.50 & 22.50 & & & & \\
\hline & Total & 18.17 & 20.17 & 18.58 & 18.92 & 18.33 & & & & \\
\hline \multirow{4}{*}{$\begin{array}{c}\text { T-Bil } \\
\mathrm{mg} / \mathrm{dL}\end{array}$} & $\mathrm{d} 7$ & 0.23 & 0.20 & 0.20 & 0.23 & 0.20 & \multirow{4}{*}{0.01} & \multirow{4}{*}{0.729} & \multirow{4}{*}{0.085} & \multirow{4}{*}{0.626} \\
\hline & d14 & 0.28 & 0.25 & 0.25 & 0.23 & 0.28 & & & & \\
\hline & $\mathrm{d} 17$ & 0.23 & 0.20 & 0.25 & 0.28 & 0.28 & & & & \\
\hline & Total & 0.24 & 0.22 & 0.23 & 0.24 & 0.25 & & & & \\
\hline \multirow{4}{*}{$\begin{array}{c}\mathrm{UA} \\
\mathrm{mg} / \mathrm{dL}\end{array}$} & $\mathrm{d} 7$ & 0.53 & 0.55 & 0.53 & 0.55 & 0.58 & \multirow{4}{*}{0.01} & \multirow{4}{*}{0.767} & \multirow{4}{*}{0.0001} & \multirow{4}{*}{0.692} \\
\hline & $\mathrm{d} 14$ & 0.65 & 0.63 & 0.60 & 0.60 & 0.65 & & & & \\
\hline & $\mathrm{d} 17$ & 0.60 & 0.60 & 0.60 & 0.63 & 0.60 & & & & \\
\hline & Total & 0.59 & 0.59 & 0.58 & 0.59 & 0.61 & & & & \\
\hline & $\mathrm{d} 7$ & 1.55 & 1.55 & 1.48 & 1.40 & 1.40 & & & & \\
\hline Cre & $\mathrm{d} 14$ & 1.30 & 1.25 & 1.10 & 1.13 & 1.08 & & & & \\
\hline $\mathrm{mg} / \mathrm{dL}$ & $\mathrm{d} 17$ & 1.28 & 1.20 & 1.20 & 1.28 & 1.23 & 0.03 & 0.231 & 0.0001 & 0.805 \\
\hline & Total & 1.38 & 1.33 & 1.26 & 1.27 & 1.23 & & & & \\
\hline $\begin{array}{l}{ }^{*} \mathrm{C} \text {, basal di } \\
\text { basal diet } \\
\text { dose of BL } \\
{ }^{* *} \text { Blood sar } \\
\text { protein }(7 . \\
\text { BUN, blood } \\
{ }^{* * *} \text { SEM, sta } \\
\text { tendency o }\end{array}$ & $\begin{array}{l}\text { t; BS, B. } \\
\text { high dose } \\
1.6 \times 10^{9} \\
\text { ple collec }\end{array}$ & $\begin{array}{l}\text { otillis ATC } \\
\text { of BS (4.8 } \\
\text { U spores } \\
\text { on: D-7: } \\
\text { T-Bil, tot } \\
\text { en (8.2-25 } \\
r \text { of the }\end{array}$ & $\begin{array}{l}1 \text { feed); } \\
\text { ays after }\end{array}$ & BL $3 \%$, & $\begin{array}{l}\text { al diet + } \\
\text { eed); BL, } \\
\text { sal diet + } \\
4: 14 \text { day } \\
\text { L); Alb, a }\end{array}$ & $\begin{array}{l}\text { gh dose } \\
\text { after we } \\
\text { umin }(2 .\end{array}$ & $\begin{array}{l}(1.6 \times 1 \\
\text { is ATCC } \\
\mathrm{L}(4.8 \mathrm{x} \\
\mathrm{ng}, \mathrm{D}-17 \\
.0 \mathrm{mg} / \mathrm{d}\end{array}$ & $\begin{array}{l}\text { CFU spc } \\
424 ; \mathrm{E} 1 \\
9^{9} \mathrm{CFU} \text { sp } \\
7 \text { days a } \\
\text { Cre, cre }\end{array}$ & $\begin{array}{l}\text { g-1 feed); } \\
1 \% \text {, basal } \\
\text { s g-1 feed). } \\
\text { weaning. } \\
\text { ine ( } 0.8-2 \text {. }\end{array}$ & $\begin{array}{l}\text { BS 3\%, } \\
\text { + + low } \\
\text { o, total } \\
\text { gg/dL); } \\
<0.10\end{array}$ \\
\hline
\end{tabular}

Regarding the period, there were noticed lower $(\mathrm{P}<0.05)$ concentrations of PUN in $7 \mathrm{~d}$ compared to $14 \mathrm{~d}$ and $17 \mathrm{~d}$. It was stated that an increased level of plasma urea nitrogen reflects the protein decomposition and a decreased level of this serum parameter reflects increase deposition of protein synthesis and improves the utilization of nitrogen (Qiu et al., 2009).

In our study, plasma T-Bil show a tendency $(\mathrm{P}=0.85)$ effect between the periods. However, we observe a difference $(\mathrm{P}<0.05)$ between $7 \mathrm{~d}$ and $14 \mathrm{~d}$, thus 
the T-Bil concentration from day 7 were lower, compared with concentration noticed in day 14 , meanwhile between $7 \mathrm{~d}$ and $17 \mathrm{~d}$ was noticed a tendency $(\mathrm{P}=0.062)$.

The UA is a product of the metabolism of purine bases and makes a useful biomarker for establishing the diagnostic of nutritional health in pigs. In our study, we observed that the diet did not affect plasma UA. However, can be seen as in day 7 the UA concentration was higher compared with day 14 and day 17. Contrary to our results Czech et al., (2018), noticed significant changes in the UA concentration when probiotics and yeasts were added in the pigs' diets.

Creatinine is a by-product produced by creatine phosphate, which is present in muscles and is eliminated from the blood by the kidney (Braun, 2008). This is an important marker that reflects on mass muscle, and it is the most commonly used to measure kidney function (Radostits et al., 2000). In our study, a significant effect for plasma creatinine values was observed in dynamic. During the study period, the higher $(\mathrm{P}<0.05)$ plasma creatinine values were observed during day 7 , compared with values from day 14 respectively day 17 . In the literature, there is a lack of data regarding the level of creatinine in weaning pigs. However, the use of Bacillus spp. maintained the creatinine plasma values within the normal range in all sampling days. Similar concentration was also observed by Yu et al., (2019). According to the same author, the increase in creatinine only at $\mathrm{d} 7$ post-weaning may be due to transient dehydration after the dietary change.

No interaction was found between diet*period regarding the plasma protein profile. No significant differences were also observed by Chen et al., (2005), who tested the effects of some probiotics (Lactobacillus acidophilus, $1.0 \times 10^{7} \mathrm{CFU} / \mathrm{g}$; Saccharomyces cerevisae, $4.3 \times 10^{6} \mathrm{CFU} / \mathrm{g}$; Bacillus subtilis $2.0 \times 10^{6} \mathrm{CFU} / \mathrm{g}$ ) in pig's diet. Contrary to our results Cai et al., 2015 notice that the inclusion of 1 strain of Bacillus subtilis and 2 strains of Bacillus amyloliquefaciens $\left(1.5 \times 10^{5} \mathrm{cfu}\right.$ spores per gram of feed) in equal proportions, decreased $(\mathrm{P}<0.05)$ the BUN concentration compared with the control group.

Plasma enzymatic profile

The liver is one of the largest and complex organs of the body, with interdependent metabolic, excretory and defense functions. However, little data is available about changes in hepatic function throughout the weaning period.

It is known that GPT and GOT play a critical role in transamination and reflect the status of protein synthesis and catabolism while the GGT catalyzes the transfer of the gamma-glutamyl group from glutathione to acceptor amino acids (Yang et al., 2001; Liu et al., 2015). According to Hyder et al., (2013), the plasma enzyme levels can fluctuate widely from normal to moderately abnormal, with values rarely into the high hundreds. The plasma biochemical enzymes of piglets are shown in Table 3. 
Table 3. Plasma enzyme profile at $7 d, 14 d$ and $17 d$ after weaning of piglets

\begin{tabular}{|c|c|c|c|c|c|c|c|c|c|c|}
\hline \multirow[b]{2}{*}{ Items } & \multirow[b]{2}{*}{ Day } & \multicolumn{5}{|c|}{ Diet } & \multirow[b]{2}{*}{ SEM } & \multicolumn{3}{|c|}{ P-value } \\
\hline & & $\mathrm{C}$ & $\begin{array}{c}\text { E1- } \\
\text { BS } \\
1 \%\end{array}$ & $\begin{array}{c}\text { E2- } \\
\text { BS } \\
3 \%\end{array}$ & $\begin{array}{l}\text { E3- } \\
\text { BL } \\
1 \%\end{array}$ & $\begin{array}{c}\text { E4-BL } \\
3 \%\end{array}$ & & Diet & Day & $\begin{array}{c}\text { Diet* } \\
\text { day }\end{array}$ \\
\hline \multirow{4}{*}{$\begin{array}{l}\text { GOT } \\
\text { UI/L }\end{array}$} & d7 & 28.50 & 26.75 & 34.00 & 22.50 & 36.75 & \multirow{4}{*}{3.93} & \multirow{4}{*}{0.199} & \multirow{4}{*}{0.07} & \multirow{4}{*}{0.588} \\
\hline & $\mathrm{d} 14$ & 40.75 & 22.25 & 78.00 & 21.00 & 59.50 & & & & \\
\hline & $\mathrm{d} 17$ & 18.00 & 25.50 & 24.00 & 27.50 & 37.00 & & & & \\
\hline & Total & 29.08 & 24.83 & 45.33 & 23.50 & 44.42 & & & & \\
\hline \multirow{4}{*}{$\begin{array}{l}\text { GPT } \\
\text { UI/L }\end{array}$} & $\mathrm{d} 7$ & 28.00 & 42.50 & 42.00 & 32.00 & 35.75 & \multirow{4}{*}{1.35} & \multirow{4}{*}{0.197} & \multirow{4}{*}{0.03} & \multirow{4}{*}{0.565} \\
\hline & d14 & 45.75 & 44.75 & 48.75 & 34.75 & 46.25 & & & & \\
\hline & $\mathrm{d} 17$ & 36.75 & 38.25 & 35.25 & 33.50 & 43.50 & & & & \\
\hline & Total & 36.83 & 41.83 & 42.00 & 33.42 & 41.83 & & & & \\
\hline \multirow{4}{*}{$\begin{array}{l}\text { CPK } \\
\text { UI/L }\end{array}$} & $\mathrm{d} 7$ & 435.7 & 352.0 & 523.7 & 372.5 & 661.75 & \multirow{4}{*}{51.4} & \multirow{4}{*}{0.092} & \multirow{4}{*}{0.54} & \multirow{4}{*}{0.812} \\
\hline & d14 & 607.5 & 432.5 & 471.0 & 322.0 & 1113.7 & & & & \\
\hline & $\mathrm{d} 17$ & 420.5 & 590.7 & 387.0 & 518.7 & 768.25 & & & & \\
\hline & Total & 487.9 & 458.4 & 460.5 & 404.4 & 847.92 & & & & \\
\hline \multirow{4}{*}{$\begin{array}{l}\text { GGT } \\
\text { UI/L }\end{array}$} & $\mathrm{d} 7$ & 60.00 & 43.25 & 35.75 & 66.00 & 45.50 & \multirow{4}{*}{2.72} & \multirow{4}{*}{0.017} & \multirow{4}{*}{0.89} & \multirow{4}{*}{0.999} \\
\hline & $\mathrm{d} 14$ & 56.25 & 57.75 & 35.50 & 61.25 & 43.75 & & & & \\
\hline & $\mathrm{d} 17$ & 51.25 & 41.50 & 35.70 & 67.00 & 40.00 & & & & \\
\hline & Total & 55.83 & 47.50 & 35.67 & 64.75 & 43.08 & & & & \\
\hline
\end{tabular}

C, basal diet; BS, B. subtilis ATCC 6051a; E1-BS 1\%, basal diet + low dose of BS $\left(1.6 \times 10^{9} \mathrm{CFU}\right.$ spores g-1 feed); E2-BS 3\%, basal diet + high dose of BS (4.8 x $10^{9} \mathrm{CFU}$ spores g-1 feed); BL, $B$. licheniformis ATCC 21424; E1-BL 1\%, basal diet + low dose of BL $\left(1.6 \times 10^{9} \mathrm{CFU}\right.$ spores g-1 feed); E2-BL 3\%, basal diet + high dose of BL ( $4.8 \times 10^{9} \mathrm{CFU}$ spores $\left.\mathrm{g}-1 \mathrm{feed}\right)$.

**Blood sample collection: D-7: 7 days after weaning, D-14: 14 days after weaning, D-17: 17 days after weaning. GOT, glutamic-oxaloacetate transaminase (22-47 IU); GPT, glutamic-pyruvic transaminase (31-75 IU); CPK, creatine phosphokinase (66-689 IU); GGT, gammaglutamyltransferase (31-52 IU); international units per litre.;

${ }^{* * *}$ SEM, standard error of the means; $\mathrm{P}<0.001$ highly significant difference; $\mathrm{P}<0.05$ significant difference; $\mathrm{P}<0.10$ tendency of influence; $\mathrm{P}>0.10$ not significant.

As it is known GGT is an indicator that identifies bile duct obstruction or cholestasis disease, intra and extrahepatic. In our study we noticed that pigs fed with E3-Bl1\% had a higher $(\mathrm{P}<0.05)$ GGT concentration compared with $\mathrm{E} 4-\mathrm{Bl} 3 \%(<33.08 \%), \mathrm{E} 1-\mathrm{Bs} 1 \%(<44.92)$ and $\mathrm{E} 2-\mathrm{Bs} 3 \%(<26.65 \%)$, while the pigs fed E1-Bs3\% had lower values compared to C (>36.11) and E3-Bl1\% (>44.92) diets. An elevated serum GGT has been associated with damaged liver function caused by hepatic cholestasis and some destruction of the hepatic cell membranes (Luo et al., 2016; Hyder et al., 2013).

Regarding GPT, this recorded significant effect as a period effect (d7, d14, d17), and GOT recorded a tendency.

Even though there was a significant difference between diets and periods, the level of these enzymes was in the normal range (Merk 2014) throughout the entire experiment, and we can conclude that DMF did not affect piglet's health. These findings are similar to those reported by (Lefter et al., 2020, Tarnoveanu et al., 2019) in weaning piglets. 
There are not observed a significant diet*period interaction, in the plasma GOT, GPT, GGT, CPK. Contrary to our results Prieto et al., (2014), feading weaning piglets with B. pumilus diet ( $10^{10}$ spores/day), registered a treatment $\mathrm{x}$ time interaction $(\mathrm{P}<0.001)$ for GGT and a tendency for for GOT

\section{Plasma lipidic profile}

The results of plasma energetic profile are summarized in Table 4.

Generally, the values of most of the plasma lipidic profile tested were within normal ranges for swine. Among the investigated lipidic profile, only the concentration of TG was significantly affected in the pigs feed with E2$\mathrm{Bs} 3 \%$ and $\mathrm{E} 3-\mathrm{Bl} 1 \%$ diets compared with the rest diet $(\mathrm{P}<0.05)$. Contrary to our results Cui et al., (2013) noticed that TG level was significantly decreased by the addition of $20 \mathrm{~g} / \mathrm{kg}$ probiotics (B. subtilis, $2.0 \times 1010 \mathrm{CFU} / \mathrm{g}$ ) in pigs diet. Also, Joysowal et al., (2018) observed a significant reduction in the TG concentration when Pediococcus acidilactici FT28 (200 g/pig/day) used as probiotic was administered in pigs diet. Dowarah et al., (2018), noticed that the TG concentration was unaffected, when administered Pediococcus acidilactici FT28 in weaning piglets diet.

Regarding the difference between periods, we observed that both T-Chol and TG plasma concentration were lower $(\mathrm{P}<0.05)$ in day 7 compared with day 17, although this value was within the range of the reference value. The overall T-Chol and TG value obtained in the present study was within the range reported by other authors (Habeanu et al., 2017 Gheorghe et al., 2018, Lefter et al., 2020)

Recorded lower glucose value in the blood of weaning piglets in day 7 could be the result of a smaller reserve of fat tissue after birth and higher glucose degradation as the energy source for body warmth maintenance.

However, we can observe that serum glucose level in all group of piglets increased during the first days following, apart from piglets fed diet Bs3\%, that register a slight decrease in day 17. According to different authors (Yadav et al., 2008; Dowarah et al., 2018), probiotic supplementation could alter gut microflora, which may be responsible for modification of gut hormone secretion and improvement of glucose homeostasis. Contrary to our results, some studies reported an increase of serum glucose level in pigs' diet in the presence of Saccharomyces cerevisiae (Kumar et al., 2012). An increase in serum glucose was also obtained by Dowarah et al., (2018) when lactic acid bacteria was added in piglet's diet.

With respect to diets and diet*period interaction no statistically significant differences in the T-Chol, HDL-C and Glu were observed. Similar results regarding T-Chol concentration were also observed by Cui et al., (2013) when added $20 \mathrm{~g} / \mathrm{kg}$ probiotics (B. subtilis, $2.0 \times 1010 \mathrm{CFU} / \mathrm{g}$ ) in pig's diet. 
Table 4. Plasma energetic profile at d7, d14 and d17 after weaning of piglets

\begin{tabular}{|c|c|c|c|c|c|c|c|c|c|c|}
\hline \multirow[b]{2}{*}{ Items } & \multirow[t]{2}{*}{ Day } & \multicolumn{5}{|c|}{ Diet } & \multirow[b]{2}{*}{ SEM } & \multicolumn{3}{|c|}{ P-value } \\
\hline & & $\mathrm{C}$ & $\begin{array}{c}\text { E1-BS } \\
1 \%\end{array}$ & $\begin{array}{c}\text { E2-BS } \\
3 \%\end{array}$ & $\begin{array}{c}\text { E3-BL } \\
1 \%\end{array}$ & $\begin{array}{c}\text { E4- } \\
\text { BL } \\
3 \%\end{array}$ & & Diet & Day & $\begin{array}{c}\text { Diet* } \\
\text { day }\end{array}$ \\
\hline \multirow{5}{*}{$\begin{array}{l}\text { T-Chol } \\
\mathrm{mg} / \mathrm{dL}\end{array}$} & $\mathrm{d} 7$ & 90.0 & 98.25 & 94.75 & 88.25 & 98.00 & \multirow{5}{*}{1.69} & \multirow{5}{*}{0.984} & \multirow{5}{*}{$\begin{array}{c}0.000 \\
1\end{array}$} & \multirow{5}{*}{0.859} \\
\hline & $\mathrm{d} 14$ & 108.5 & 112.5 & 111.7 & 109.0 & 108.0 & & & & \\
\hline & $\mathrm{d} 17$ & 108.0 & 107.0 & 105.5 & 111.5 & 105.0 & & & & \\
\hline & \multirow{2}{*}{ Total } & \multirow{2}{*}{102.1} & 105.9 & 104.0 & 102.9 & 103.6 & & & & \\
\hline & & & 2 & 0 & 2 & 7 & & & & \\
\hline & $\mathrm{d} 7$ & 28.75 & 37.25 & 35.75 & 39.50 & 38.75 & \multirow{4}{*}{1.19} & \multirow{4}{*}{0.443} & \multirow{4}{*}{0.115} & \multirow{4}{*}{0.789} \\
\hline HDL-C & d14 & 44.25 & 48.00 & 39.25 & 46.25 & 38.50 & & & & \\
\hline \multirow[t]{2}{*}{$\mathrm{mg} / \mathrm{dL}$} & $\mathrm{d} 17$ & 39.00 & 43.25 & 35.25 & 41.25 & 37.50 & & & & \\
\hline & Total & 37.33 & 36.75 & 42.83 & 42.33 & 38.25 & & & & \\
\hline & $\mathrm{d} 7$ & 19.75 & 32.75 & 43.00 & 40.50 & 32.75 & \multirow{4}{*}{2.33} & \multirow{4}{*}{0.048} & \multirow{4}{*}{0.003} & \multirow{4}{*}{0.734} \\
\hline TG & d14 & 41.75 & 30.50 & 51.75 & 44.25 & 35.25 & & & & \\
\hline \multirow[t]{2}{*}{$\mathrm{mg} / \mathrm{dL}$} & $\mathrm{d} 17$ & 48.00 & 44.75 & 57.25 & 68.25 & 41.50 & & & & \\
\hline & Total & 36.50 & 36.00 & 50.67 & 51.00 & 36.50 & & & & \\
\hline & $\mathrm{d} 7$ & 108.7 & 103.0 & 102.2 & 94.25 & 95.75 & \multirow{4}{*}{2.14} & \multirow{4}{*}{0.238} & \multirow{4}{*}{0.086} & \multirow{4}{*}{0.243} \\
\hline Glu & $\mathrm{d} 14$ & 116.2 & 99.5 & 108.5 & 97.00 & 114.2 & & & & \\
\hline \multirow[t]{2}{*}{$\mathrm{mg} / \mathrm{dL}$} & $\mathrm{d} 17$ & 112.2 & 116.0 & 91.0 & 114.7 & 123.0 & & & & \\
\hline & Total & 112.4 & 106.1 & 100.5 & 102.0 & 111.0 & & & & \\
\hline
\end{tabular}

${ }^{*} \mathrm{C}$, basal diet; BS, B. subtilis ATCC 6051a; E1-BS 1\%, basal diet + low dose of BS $\left(1.6 \times 10^{9} \mathrm{CFU}\right.$ spores g-1 feed); E2-BS 3\%, basal diet + high dose of BS (4.8 $\times 10^{9}$ CFU spores g-1 feed); BL, $B$. licheniformis ATCC 21424; E1-BL 1\%, basal diet + low dose of BL $\left(1.6 \times 10^{9}\right.$ CFU spores g-1 feed); E2-BL 3\%, basal diet + high dose of BL ( $4.8 \times 10^{9} \mathrm{CFU}$ spores $\mathrm{g}-1$ feed).

**Blood sample collection: D-7: 7 days after weaning, D-14: 14 days after weaning, D-17: 17 days after weaning. T-Chol, total cholesterol (67.0-377 mg/dL); HDL-C, high-density lipoprotein cholesterol (38.7-48.3 mg/dL); TG, triglyceride (33 - $50 \mathrm{mg} / \mathrm{dL})$; Glu, Glucose.

***SEM, standard error of the means; $\mathrm{P}<0.001$ highly significant difference; $\mathrm{P}<0.05$ significant difference; $\mathrm{P}<0.10$ tendency of influence; $\mathrm{P}>0.10$ not significant.

Contrary to our results Balasubramanian et al. (2016), that included $0.01 \%$ respectively $0.02 \%$ Bacillus spp. as probiotics in pig's diet, noticed a significant increase on Glu concentration. Also, Dowarah et al., (2018) observed that the serum glucose concentration was highest $(\mathrm{P}<0.001)$ in supplemented groups compared with control, and that animals fed $P$. acidilactici FT had better serum glucose than pigs fed with L. acidophilus.

\section{Plasma mineral profile}

Calcium (Ca) and Phosphorus (P) are one of the most essential elements, with a vital role in growth processes, formation and stability of bones, and maintenance of physiological cell metabolism (Gerlinger et al., 2019). In pigs, about $99 \%$ of the calcium and $80 \%$ of the phosphorus in the body are found in the skeleton, and when there are deficiencies and surpluses, this macrominerals have considerable effects on bone mineral content and 
density, bone composition, and development (Liesegang et al., 2002; Gerlinger et al., 2019).

Table 5. Plasma mineral profile at d7, d14 and d17 after weaning of piglets

\begin{tabular}{|c|c|c|c|c|c|c|c|c|c|c|}
\hline \multirow[b]{2}{*}{ Items } & \multirow[b]{2}{*}{ Day } & \multicolumn{5}{|c|}{ Diet } & \multirow[b]{2}{*}{ SEM } & \multicolumn{3}{|c|}{ P-value } \\
\hline & & $\mathrm{C}$ & $\begin{array}{c}\text { E1-BS } \\
1 \%\end{array}$ & $\begin{array}{c}\text { E2-BS } \\
3 \%\end{array}$ & $\begin{array}{c}\text { E3-BL } \\
1 \%\end{array}$ & $\begin{array}{c}\text { E4-BL } \\
3 \%\end{array}$ & & Diet & Day & Diet*day \\
\hline \multirow{4}{*}{$\begin{array}{c}\mathrm{Ca} \\
\mathrm{mg} / \mathrm{d} \\
\mathrm{L}\end{array}$} & $\mathrm{d} 7$ & 15.2 & 15.68 & 15.25 & 14.88 & 15.28 & \multirow{4}{*}{0.15} & \multirow{4}{*}{0.052} & \multirow{4}{*}{0.097} & \multirow{4}{*}{0.157} \\
\hline & d14 & 15.4 & 15.28 & 13.45 & 15.30 & 15.43 & & & & \\
\hline & $\mathrm{d} 17$ & 14.4 & 13.88 & 13.53 & 14.90 & 15.83 & & & & \\
\hline & Total & 15.0 & 14.94 & 14.08 & 15.03 & 15.51 & & & & \\
\hline \multirow{4}{*}{$\begin{array}{c}\mathrm{Mg} \\
\mathrm{mg} / \mathrm{d} \\
\mathrm{L}\end{array}$} & $\mathrm{d} 7$ & 2.53 & 2.45 & 2.20 & 2.30 & 2.10 & \multirow{4}{*}{0.04} & \multirow{4}{*}{0.001} & \multirow{4}{*}{0.029} & \multirow{4}{*}{0.005} \\
\hline & d14 & 2.90 & 2.63 & 2.10 & 2.55 & 2.20 & & & & \\
\hline & $\mathrm{d} 17$ & 2.20 & 2.10 & 2.15 & 2.48 & 2.25 & & & & \\
\hline & Total & 2.54 & 2.39 & 2.15 & 2.44 & 2.18 & & & & \\
\hline \multirow{4}{*}{$\begin{array}{c}\text { IP } \\
\mathrm{mg} / \mathrm{d} \\
\mathrm{L}\end{array}$} & $\mathrm{d} 7$ & 6.73 & 7.00 & 6.93 & 6.93 & 7.38 & \multirow{4}{*}{0.17} & \multirow{4}{*}{0.912} & \multirow{4}{*}{0.001} & \multirow{4}{*}{0.696} \\
\hline & d14 & 9.85 & 9.23 & 8.93 & 8.78 & 8.40 & & & & \\
\hline & $\mathrm{d} 17$ & 8.25 & 8.48 & 7.90 & 8.28 & 7.85 & & & & \\
\hline & Total & 8.23 & 8.23 & 7.92 & 7.99 & 7.88 & & & & \\
\hline
\end{tabular}

${ }^{*} \mathrm{C}$, basal diet; BS, B. subtilis ATCC 6051a; E1-BS 1\%, basal diet + low dose of BS $\left(1.6 \times 10^{9} \mathrm{CFU}\right.$ spores g-1 feed); E2-BS 3\%, basal diet + high dose of BS (4.8 x $10^{9} \mathrm{CFU}$ spores g-1 feed); BL, $B$. licheniformis ATCC 21424; E1-BL 1\%, basal diet + low dose of BL $\left(1.6 \times 10^{9} \mathrm{CFU}\right.$ spores g-1 feed); E2-BL 3\%, basal diet + high dose of BL ( $4.8 \times 10^{9}$ CFU spores g-1 feed).

**Blood sample collection: D-7: 7 days after weaning, D-14: 14 days after weaning, D-17: 17 days after weaning. Ca, calcium (6.8-14.8 mg/dL); $\mathrm{Mg}$, magnesium (2.3-3.5 mg/dL); IP, inorganic phosphorus (8.66 - $13.31 \mathrm{mg} / \mathrm{dL})$.

***SEM, standard error of the means; $\mathrm{P}<0.001$ highly significant difference; $\mathrm{P}<0.05$ significant difference; $\mathrm{P}<0.10$ tendency of influence; $\mathrm{P}>0.10$ not significant.

The macro-minerals concentration in the blood plasma depends on the nutritional composition of the diet, age and physiological state of the animal. In our study, the plasma Mg concentration (Table 5) was significantly affected by the diet, day and diet*day interaction, meanwhile IP registered was affected $(\mathrm{P}<0.05)$ by the day. In our study the lowest $\mathrm{Mg}$ concentration was noticed in pigs fed $\mathrm{E} 2-\mathrm{Bs} 3 \%$ and $\mathrm{E} 4-\mathrm{Bl} 3 \%$ diets. Thus, piglets that received $\mathrm{E} 2-$ BS 3\% diet registered lower $(\mathrm{P}<0.05) \mathrm{Mg}$ plasma concentration compared with E1-BS 1\% (>10.05\%), E3-BL 1\% (>11.89) and C (>15.36\%) diet.

The E2-BS 3\% diet tended to decrease the piglets plasma Ca concentration compared with the rest of the experimental diets. However, the diets had no influence $(\mathrm{P}>0.05)$ on $\mathrm{P}$ plasma concentration. The plasma mineral parameters obtained in our study are in agreement with other studies (Habeanu et al, 2017 Gheorghe et al, 2018, Lefter et al, 2020.)

\section{CONCLUSION}

Weaning piglets fed diets with and without Bacillus spp. supplementation had comparable plasma biochemical concentration. Some of the investigated 
plasma parameters provided supportive evidence in assessing the influence of the period factor on the physiological condition of the pigs. The significant differences we found between periods for these biochemical parameters might be related both to piglets growth. By providing a DFM based on viable spores of B. subtilis ATCC 6051a and B. licheniformis ATCC 21424 to piglets during the weaning crisis did not have a significant influence on piglet's health status. However, the blood and plasma biochemical values of the weaning piglets should be further investigated.

\section{ACKNOWLEDGEMENTS}

This research was funded by the Romanian Ministry of Education and Research through project 8PCCDI/2018 pc2.

\section{REFERENCES}

Baker, A.A., Davis, E., Spencer, J.D., Moser, R., Rehberger, T. 2013. The effect of a Bacillus-based direct-fed microbial supplemented to sows on thegastrointestinal microbiota of their neonatal piglets. J Anim Sci. 91:3390-9

Balasubramanian, B., Li, T., Kim, I.H. 2016. Effects of supplementing growingfinishing pig diets with Bacillus spp. probiotic on growth performance and meat-carcass grade quality traits. Rev. Bras .Zootec., $45,93-100$

Chen, Y.J., Son K.S., Min, B.J., Cho, J.H., Kwon, O.S. and Kim, I.H. 2005. Effects of dietary probiotic on growth performance, nutrients digestibility, blood characteristics and fecal noxious gas content in growing pigs. AsianAust. J. Anim. Sci. Vol 18, No. 10 : 1464-1468.

Cui, C., Shen, C.J., Jia, G. and Wang, K.N. (2013) Effect of dietary Bacillus subtilis on proportion of Bacteroidetes and Firmicutes in swine intestine and lipid metabolism. Genet. Mol. Res., 12(12): 1766-1776.

Dong, X., Zhang, N., Zhou, M., Tu, Y., Deng, K. and Diao, Q. 2013. Effects of dietary probiotics on growth performance, faecal microbiota and serum profiles in weaned piglets. Animal Production Science 54(5) 616-621 https://doi.org/10.1071/AN12372.

Dowarah, R., Verma, A,K., Agarwal, N., Singh, P., Singh, B.R. 2018. Selection and characterization of probiotic lactic acid bacteria and its impact on growth, nutrient digestibility, health and antioxidant status in weaned piglets. PLoS ONE 13(3): e0192978. https://doi.org/10.1371/journal. pone.0192978

Diamini, Z.C., Langa, R.L.S., Aiyegoro, O.A., Okoh, A.I. 2017. Effects of probiotics on growth performance, blood parameters, and antibody stimulation in piglets. South African Journal of Animal Science, 47 (6): 767-775. DOI: $10.4314 /$ sajas.v47i6.4 
Dumitru, M., Hăbeanu, M., Lefter, N., Gheorghe, A. 2020. The effect of Bacillus licheniformis as direct-fed microbial product on growth performance, gastrointestinal disorders and microflora population in weaning piglets. Rom. Biotechnol. Lett., 25(6):2060-2069. DOI: $10.25083 / \mathrm{rbl} / 25.6 / 2060.2069$

Dumitru, M., Hăbeanu, M., Lefter, N. 2020. Effects of direct-feed microbial Bacillus supplementation on piglet's microbiota. Scientific Bulletin. Series F. Biotechnologies, Vol. XXIV(2):154-160.

Dumitru, M., Hăbeanu, M., Tabuc, C., Jurcoane, Ș. 2019. Preliminary characterization of the probiotic properties of a bacterial strain for used in monogastric nutrition. Bulletin UASVM Animal Science and Biotechnologies 76(2): 102-108.

Dumitru, M., Sorescu, I., Hăbeanu, M., Tabuc, C., Idriceanu, L., Jurcoane Ș. 2018. Preliminary characterisation of Bacillus subtilis strain use as dietary probiotic bio-additive in weaning piglet. J. Food and Feed Research, 45 (2):203-211.

Gerlinger, C., Oster, M., Borgelt, L., Reyer, H., Muráni, E., Ponsuksili, S., Polley, C., Vollmar, B., Reichel, M., Wolf, P., Wimmers, K. 2019. Physiological and Transcriptional Responses in Weaned Piglets Fed Diets with Varying Phosphorus and Calcium Levels. Nutrients, 11(2):436. doi: 10.3390/nu11020436. PMID: 30791512; PMCID: PMC6412343.

Kim, S.W., Weaver, A.C., Shen, Y.B. \& Zhao, Y. 2013. Improving efficiency of sow productivity: Nutrition and health. J. Anim. Sci. Biotechnol., 4-26. doi:10.1186/2049-1891-4-26.

Kumar, S., Verma, A.K., Mondal, S.K., Gupta, M., Patil, A., Jangi, B.L. 2012. Effect of live Saccharomyces cerevisiae feeding on serum biochemistry in early weaned cross bred piglets. Vet. World, 5(11), 663-666.

EFSA (European Food Safety Authority). 2010. Scientific Opinion on the maintenance of the list of QPS biological agents intentionally added to food and feed (2010 update). EFSA J.8:1944. doi:10.2903/j.efsa.2010.1944 .

Esonu, B.O., Enenalom, O.O., Udedibie, A.B.I., Herbert, U., Ekpor, C.F., Okoli, I.C. and Iheukwumere, F.C. 2001. Performance and blood chemistry of weaner pigs fed raw mucuna (velvet bean) meal. Trop. Anim. Prod Invest. 4: $49-55$.

Gaggia, F., Mattarelli, P., Biavati, B. 2010. Probiotics and prebiotics in animal feeding for safe food production. Int J Food Microbiol, 141, pp. S15S28.

Gheorghe, A., Hăbeanu, M., Lefter, N.A. and Grigore, D.M. 2018. Effect of dietary extruded linseed and walnut meal mixture $(8: 1)$ on performance and plasma protein profile in weaned piglets. Bulletin UASVM Animal Science and Biotechnologies, 75(2), 121-126. 
Hăbeanu, M., Lefter, N.A., Gheorghe, A., Tabuc, C., Untea, A., Surdu, I., Ciurescu, G., Balan C.G. and Dragomir, C. 2015. Changes in certain serum and faeces parameters in weaned piglets as a response to nutritional stress. South African Journal of Animal Science, 45 (No. 2).

Hăbeanu, M., Lefter, N., George, A., Tabuc, C., Dumitru, M., Ciruescu, G., and Palade, M. 2017. Effects of dietary peas mixed with linseed (3: 1) on the growth performance, enteritis and certain serum parameter in weaned piglets. Food and Feed Research, 44(2), 173-180.

$\mathrm{Hu}, \mathrm{J} ., \mathrm{Kim}, \mathrm{Y} . \mathrm{H} ., \mathrm{Kim}, \mathrm{I} . \mathrm{H} ., 2$ 2020. Effects of two Bacillus strains probiotic supplement on reproduction performance, nutrient digestibility, blood profile, fecal score, excreta odor contents and fecal microflora in lactation sows, and growth performance in sucking piglets. Livestock Scien., in press: https://doi.org/10.1016/j.livsci.2020.104293.

Hyder, M.A., Hasan, M. and Mohieldein, A.H. 2013. Comparative levels of ALT, AST, ALP and GGT in liver associated diseases. European Journal of Experimental Biology, vol. 3, no. 2, pp. 280-284.

Jin, Y.H., Oh, H.K., Piao, L.G., Jang, S.K., Choi, Y.H., Heo, P.S., Jang, Y. D., and Kim, Y.Y. 2010. Effect of dietary lysine restriction and energy density on performance, nutrient digestibility and meat quality in finishing pigs. Asian Australas J Anim Sci 23, 1213-1220.

Joysowal, M., Saikia, B. N., Dowarah, R., Tamuly, S., Kalita, D., \& Choudhury, K. D. (2018). Effect of probiotic Pediococcus acidilactici FT28 on growth performance, nutrient digestibility, health status, meat quality, and intestinal morphology in growing pigs. Veterinary world, 11(12), 1669-1676.

Larsen, N., Thorsen, L., Kpikpi, E.N., Stuer-Lauridsen, B., Cantor, M.D., Nielsen, B., 2014. Characterization of Bacillus spp. strains for use as probiotic additives in pig feed. Appl Microbiol Biotechnol. 98:1105-18. doi:10.1007/s00253-013-5343-6.

Lefter, N.A., Hăbeanu, M., Gheorghe, A., Idriceanu, L., Cirebea, M. 2020. Preliminary research on growth response and health status of piglets fed millet grain as a partial replacement for triticale. Scientific Papers. Series D. Animal Science. Vol. LXIII, No. 1

Liao, S.F., Nyachoti, M., 2017. Using probiotics to improve swine gut health and nutrient utilization. Animal nutrition, 3: 331-343.

Liesegang, B.A.L.; Ursprung, R.U.; Gasser, J.G.; Sassi, M.S.; Risteli, J.R.; Riond, J.L., Wanner, M. 2002. Influence of dietary phosphorus deficiency with or without addition of fumaric acid to a diet in pigs on bone parameters. J. Anim. Physiol. Anim. Nutr., 86, 1-16.

Merck and Co. 2010. The Merck Veterinary Manual, 10th(Eds.), Merck Co., Inc., Kenilworth, NJ, USA.

Perri, A. M., O’Sullivan, T. L., Harding, J. C. S, Wood, R. D., Friendship, R. M., Haematology and biochemistry reference intervals for Ontario 
commercial nursing pigs close to the time of weaning. Canadian Veterinary Journal, 2017, 58(4), 371-376.

Prieto M.L., O’Sullivan L., Tan S.P., McLoughlin P., Hughes H., et al. 2014. Evaluation of the Efficacy and Safety of a Marine-Derived Bacillus Strain for Use as an In-Feed Probiotic for Newly Weaned Pigs. PLoS ONE 9(2): e88599. doi:10.1371/journal.pone.0088599

SPSS .2011. Statistics v. 20.0., IBM, SPSS, Inc., USA.

Susan, E. Fielder, Serum Biochemical Reference Ranges. Available online: https://www.merckvetmanual.com/special-subjects/referenceguides/serum-biochemical-reference-ranges

Wang, Y., Cho, J.H., Chen, Y.J., Yoo, J.S., Huang, Y., Kim, H.J., 2009. The effect of probiotic BioPlus $2 \mathrm{~B} \AA$ on growth performance, dry matter and nitrogen digestibility and slurry noxious gas emission in growing pigs. Livest Sci. 120:35-42. doi:10.1016/j.livsci.2008.04.018 .

Whittemore, C.T., Green, D.M. 2006. Growth of the young weaned pig. In: Varley MA, Wiseman J (eds) The Weaner Pig. Wallingford, CAB, UK, pp 1-15.

Yang, H., Fu, Y., Chen, A.G. 2001. Relationship between blood biochemical indice and production performance in pigs. Animal science abroad. 1:34-37.

Yadav, H., Jain, S., Sinha, P.R. 2008. Oral administration of dahi containing probiotic Lactobacillus acidophilus and Lactobacillus casei delayed the progression of streptozotocin-induced diabetes in rats. J Dairy Res. May; 75(2):189-95.

Yu, K., Canalias, F., Solà-Oriol, D., Arroyo, L., Pato, R., Saco, Y., Terré, M. and Bassols, A. 2019. Age-Related Serum Biochemical Reference Intervals Established for Unweaned Calves and Piglets in the Post-weaning Period. Front. Vet. Sci. 6:123. doi: 10.3389/fvets.2019.00123.

Zhao, P.Y., Kim, I.H., 2014. Effect of direct-fed microbial on growth performance, nutrient digestibility, fecal noxious gas emission, fecal microbial flora and diarrhea score in weanling pigs. Animal Feed Science and http://dx.doi.org/10.1016/j.anifeedsci.2014.12.010 